\title{
Ahlaki Öfke Ölçeğinin Türkçeye Uyarlanması
}

Melis ÇELIK OK ${ }^{1}$

\section{ÖZET}

Bu çalışmanın amacı Ahlaki Öfke Ölçeğini Türkçeye uyarlamaktır. Çalışma 251 üniversite öğrencisinin katılımıyla gerçekleştirilmiştir. Çalışmada kullanılan veri toplama araçları; Ahlaki Öfke Ölçeği (AÖÖ), Sosyal Baskınlık Yönelimi Ölçeği (SBYÖ) ve Sağ Kanat Yetkeciliği Ölçeği (SKYÖ)'dir. Açımlayıcı faktör analizi, Ahlaki Öfke Ölçeği için iki faktörlü bir yapı önermiş; bu faktörler maddelerin içerikleri göz önünde bulundurularak, Duygusal Boyut (DB) ve Bilişsel Boyut (BB) olarak adlandırılmıştır. Doğrulayıcı faktör analizi ise ölçeğin iki faktörlü yapısını doğrulamıştır. Gerçekleştirilen geçerlilik güvenirlik analizleri toplu olarak değerlendirildiğinde, Ahlaki Öfke Ölçeğinin ülkemizdeki çalışmalarda kullanılabilecek psikometrik özelliklere sahip olduğu görülmektedir.

Anahtar Kelimeler: ahlaki öfke, ahlaki öfke ölçeği, adaletsizlik, eşitsizlik, olumlu sosyal eylem.

\section{Adaptation Of Moral Outrage Scale Into Turkısh}

\begin{abstract}
The purpose of this study is to adapt Moral Outrage Scale into Turkish. The sample of the study consisted of 251 university students. For data collection, Moral Outrage Scale, Social Dominance Orientation Scale and Rightwing Authoritarianism Scale were used. Exploratory factor analyses suggested a two-factored structure. Considering scale items' contents, these factors are called as Emotional Dimension and Cognitive Dimension. Confirmatory factor analysis confirmed the two-factored structure of the scale. Results of validity and reliability analysis altogether indicate that Moral Outrage Scale has sufficient psychometric properties to be used in research in our country.
\end{abstract}

Keywords: moral outrage, moral outrage scale, injustice, inequality, prosocial behavior.

\section{GíRiş}

Öfke, genel olarak, kişinin hedefine yönelik bir tıkanma ya da hayal kırıklığına verdiği tepki olarak tanımlanmakta ve ahlaki olmayan bir duygu olarak ele alınmaktadır (bkz., Rozin, Lowery, Imada ve Haidt, 1999). Bu bakış açısı, öfkeyi disiplinsiz, kaba saba, intikama susamış, açgözlü bir benliğin ilkesiz bir kölesi olarak görmektedir (bkz., Flanagan, 2018). Ancak öfkenin ilkel bir duygu olarak ele alınmasının yanı sıra, ahlaki bir duygu olarak daha geniş bir kapsamda da değerlendirildiği görülmektedir (Flanagan, 2018; Rozin ve ark., 1999). Buna göre, kişi ahlaki bir standart veya ilke ihlal edildiği zaman ahlaki öfke hissetmektedir. Daha ayrıntılı bir tanımla, ahlaki öfke kişinin kendisinden daha şansız olanların dezavantajları nedeniyle hissettiği ve genellikle hakkaniyet ve adalet gibi ahlaki bir standardın ihlal edilmesiyle ortaya çıkan bir duygu olarak tanımlanmaktadır (Hoffman, 2000; Montada ve Schneider, 1989). Buradan hareketle, bu çalışmanın amacı Montada ve Schneider (1989) tarafından geliştirilen Ahlaki Öfke Ölçeğini Türkçeye kazandırmaktır. Bu doğrultuda öncelikle ahlaki öfke ile ilişkili alanyazın bulgularına yer verilecektir.

\footnotetext{
${ }^{1}$ Dr. Psk., melis.celik@gmail.com
} 
Montada (1992), siyasi hareketlerin, isyanların ve devrimlerin çoğunun ahlaki öfke ile motive edildiğini belirtmektedir. Totaliter sistemlerde, ahlaki öfkenin insanları direniş hareketlerine katılmaya ve intikam almaya güdülediğini ifade etmektedir. Bunun yanında, Montada ve Schneider'a (1989) göre ahlaki öfke, adaletsizliğin değerlendirilmesine ve algılanan adaletsizliğin varlığından ya da adaletin yeniden kurulmasından sorumlu tutulanlara karşı bir suçlamada bulunmasına neden olur. Ahlaki sorumluluk açısından düşünüldüğünde ise; ahlaki öfke, sorumluluğu üçüncü bir tarafa, hatalı davranıştan veya bir görevi (muhtaç bir kişiyi desteklemek gibi) ihmal etmekten sorumlu olan bir temsilci ya da kuruma yükleme anlamını taşır. Bununla birlikte, ahlaki öfke dezavantajları azaltmaya yönelik siyasi eylemlerde bizzat yer alma ile siyasi sorumluluğu olanları ve dezavantajlı kişilere yardım edebilecek kaynakları gösteren bir sorumluluk duygusu taşıma ile ilişkilendirilebilir.

$\mathrm{Bu}$ fikirlerden hareketle, Montada ve Schneider (1989), eğitim, zenginlik ya da sosyal güvenlik açısından ayrıcalıklı statüye sahip kişilerin, dezavantajlı grupların sorunları ve ihtiyaçlarıyla yüzleştirildiklerinde verdikleri duygusal tepkileri araştırmıştır. Çalışmalarında işsizler, gelişmekte olan ülkelerdeki yoksullar ve Batı Almanya'daki yabancı işçiler olmak üzere üç dezavantajlı gruba yönelik duygusal tepkileri ölçmüşlerdir. Söz konusu dezavantajlı gruplara yönelik sempati, kişinin görece kendisinin sahip olduğu avantajlar yüzünden hissettiği varoluşsal suçluluk, daha şanssız grupların adaletsiz olan dezavantajlı durumları için hissedilen ahlaki öfke, kişinin kendi avantajlı durumundan duyduğu memnuniyet, geleceğe ilişkin umutsuzluk, kendi avantajını kaybetme korkusu ve dezavantajlılara karşı duyulan kızgınlık duygularını incelemişlerdir. Araştırma bulguları en çok hissedilen duygunun kişinin kendi avantajlı durumundan duyduğu memnuniyet olduğunu göstermektedir. Memnuniyeti sırasıyla sempati, ahlaki öfke, umutsuzluk, suçluluk, korku ve kızgınlık duyguları izlemektedir. Ayrıca dezavantajlı gruplara yardım etmeyle ilişkili olumlu sosyal eylemler sergileme yönündeki taahhüdü en güçlü yordayan duygunun ahlaki öfke olduğu, onu varoluşsal suçluluğun izlediği bulunmuştur. Diğer bir deyişle, yazarların öngördüğü gibi, ahlaki öfke ve varoluşsal suçluluk arttıkça, dezavantajlı gruplara yardım etme yönündeki isteklilik de artmaktadır. Bu sonuçlar olumlu sosyal eylemlerde bulunmaya yönelik motivasyon açısından ahlaki öfkenin önemli bir değişken olduğunu ortaya koymaktadır.

Montada ve Schneider (1989) tarafindan ortaya koyulan bulgular, adaletsiz bir duruma verilen duygusal bir tepki olan ahlaki öfkenin, sistemi meşrulaştırma ile ilişkili olduğunu düşündürmektedir. Sistemi Meşrulaştırma Kuramının amaçlarından biri, var olan toplumsal, ekonomik ve siyasi düzenlemelerin iyi, adil, yasal ve istenir olduğunu benimsemenin psikolojik faydalarını açıklayabilmektir (Jost, 2011). Örneğin Jost ve Hunyady (2002), sistemi meşrulaştırmanın toplumsal konumdan bağımsız olarak bireylerin kaygı, suçluluk, belirsizlik gibi duygularının azalmasını sağlayarak hafifletici bir etkide bulunduğuna işaret etmektedir. Benzer bir şekilde, Jost, Wakslak ve Tyler (2008) tarafından yapılan bir çalışmada, avantajlı grup üyeleri için sistemi meşrulaştırıcı ideoloji, suçluluğu azaltırken; dezavantajlı grup üyelerinde hayal kırıklığını azaltmış; bütün gruplarda da memnuniyeti artırmıştır. Bu bulgularla paralel olarak, ahlaki öfkenin sistemi meşrulaştırmanın bir bileşeni olan bireylerin eşitliğe karşı olma düzeyleri ile ilişkili olduğu bulunmuştur (Wakslak, Jost, Tyler ve Chen, 2007). Buna göre ahlaki öfke ve varoluşsal suçlulukla, eşitliğe karşı olma arasında negatif bir ilişki vardır. Ancak eşitliğe karşı olma yani sistemi meşrulaştırma ile kaynakların yeniden dağıtımına ilişkin politikalara destek arasındaki ilişkiye ahlaki öfke aracılık etmektedir. Yani sistemi meşrulaştırma arttıkça, ahlaki öfke azalmakta ve ahlaki öfke azaldıkça yeniden dağıtım politikalarına yönelik destek de azalmaktadır. Bununla birlikte bu aracılık ilişkisi varoluşsal suçluluk için geçerli değildir. Araştırmacılar yaptıkları ikinci çalışmada yüksek sistemi meşrulaştırma deneysel koşulundaki katılımcıların, düşük sistemi meşrulaştırma grubundaki katılımcılardan daha az olumsuz duygu ve ahlaki öfke bildirdiklerini bulmuşlardır. Ahlaki öfke ilk çalışmadakine benzer olarak bu çalışmada da, sistemi meşrulaştırma ile kaynakların yeniden dağıtımına ilişkin politikalara destek arasındaki ilişkiye aracılık etmekte, ancak olumsuz duygu aracılık etmemektedir.

Kugler, Cooper ve Nosek (2010), sosyal baskınlık yöneliminin iki bileşeni olan eşitliğe karşı olma ve grup temelli baskınlığın farklı motivasyonlardan kaynaklandığı fikrinden yola çıkarak; eşitliğe karşı olmanın kaynakların yeniden dağıtımı politikalarına yönelik tutumları, politik tutuculuğu ve dezavantajlılara yönelik insancıllık duygularını daha güçlü yordayacağını; grup temelli baskınlığın ise sosyal kimliğe yönelik motivasyonları yansıtacağını öngörmüşlerdir. Bu doğrultuda eşitsizliğe yönelik duygusal tepkilerin (varoluşsal suçluluk, kolektif suçluluk ve ahlaki öfke), eşitliğe karşı olma ile daha kuvvetli bir ilişkisinin olmasını beklemişler ve bu beklentileri doğrulanmıştır. Yani eşitliğe karşı olma; 
varoluşsal ve kolektif suçluluk ile ahlaki öfkeyi negatif olarak yordamış; grup temelli baskınlık ise bu değişkenlerin hiçbirini anlamlı olarak açıklamamıştır.

Ahlaki öfke ile sosyal baskınlık yönelimi ve yolsuzluk farkındalığı arasındaki ilişkiler de incelenmiştir (Tan, Liu, Huang, Zhao ve Zheng, 2016). Söz konusu araştırmada, katılımcıların sözde liderlik becerilerine yönelik geribildirimleri değişimlenerek sosyal baskınlık yönelimi düzeyleri değişimlenmiştir. Liderlik becerileri yüksek katılımcılarda sosyal baskınlık yöneliminin yüksek, liderlik becerileri düşük olan katılımcılarda ise sosyal baskınlık yöneliminin düşük olması beklenmiştir. $\mathrm{Bu}$ değişimleme dört maddeye indirgenmiş Sosyal Baskınlık Yönelimi Ölçeği ile değerlendirilmiştir. Sosyal olarak baskın koşulda bulunan katılımcıların sosyal baskınlık yönelimi puanları, diğer gruptan daha yüksek olarak bulunmuştur. Araştırma sonucunda yüksek sosyal baskınlık yönelimi koşulundaki katılımcıların ahlaki öfke ve yolsuzluk farkındalı̆̆ı puanlarının düşük sosyal baskınlık yönelimi koşulundaki katılımcılarınkinden daha düşük olduğu bulunmuştur. Araştırmada ayrıca, ahlaki öfkenin sosyal baskınlık yönelimi ve yolsuzluk farkındalığı arasındaki negatif ilişkiye aracılık ettiği bulunmuştur. Yani sosyal baskınlık yönelimi arttıkça ahlaki öfke azalmakta, bu da yolsuzluk farkındalığını azaltmaktadır. Bir başka çalışmada ise benzer bir şekilde ahlaki öfkenin sosyal baskınlık yönelimi ile yolsuzluk niyeti arasındaki pozitif ilişkiye kısmi aracılık ettiği; sağ kanat yetkeciliği ile yolsuzluk niyeti arasındaki pozitif ilişkiye ise tam aracılık ettiği bulunmuştur (Tan, Liu, Zheng ve Huang, 2016). Diğer bir deyişle, sosyal baskınlık yönelimi ve sağ kanat yetkeciliği arttıkça ahlaki öfke azalmakta, yolsuzluk niyeti ise artmaktadır. İki çalışmanın bulguları genel olarak değerlendirildiğinde, baskın gruplarda ahlaki öfkenin düşük olmasının, adaletsizlikle ilişkili bir durum olan yolsuzluk üzerinde etkili olduğu; yolsuzluk farkındalığını azaltırken, yolsuzluk niyetini artırdığı görülmektedir.

Sistemi meşrulaştırma ve ahlaki öfke arasındaki ilişki, toplumsal cinsiyet sistemi düzleminde de araştırılmıştır. Buna göre, ahlaki öfke, hem tecavüz sonrası kadını suçlama eğilimiyle hem de cinsiyetle ilgili sistemi meşrulaştırma ile ilişkilidir (Chapleau ve Oswald, 2014). Chapleau ve Oswald (2014) cinsiyetle ilgili sistemi meşrulaştırma düzeyi ile ahlaki öfke arasında negatif, tecavüz mitlerini kabul arasında ise pozitif ilişki bulmuşlardır. Araştırmacılar ayrıca cinsiyetle ilgili sistemi meşrulaştırma kontrol edildiğinde tecavüz mitlerini kabul ile ahlaki öfke arasında negatif yönde bir ilişkinin olduğunu belirtmişlerdir. Ek olarak erkeklerin cinsiyetle ilgili sistemi meşrulaştırma ve tecavüz mitleri düzeyleri kadınlarınkinden marjinal düzeyde daha yüksek; ahlaki öfke düzeyleri ise yine marjinal olarak daha düşüktür. Ayrıca kadınların cinsiyetle ilgili sistemi meşrulaştırma düzeyleri de ahlaki öfke düzeyini ve tecavüz mitlerini kabul düzeyini erkeklerinki kadar iyi yordamaktadır. Araştırmacılar bu bulgulardan yola çıkarak, tecavüz mitlerini kabulün kadınlar için sistemi meşrulaştırıcı bir işlevinin olduğu sonucuna varmışlardır. Onlara göre, bir erkeğin bir kadına cinsel saldırıda bulunmasının, kadının başarısızlığından kaynaklandığı inancı nedeniyle, erkeklerden, toplumdaki baskın grup olarak, davranışlarını ayarlamaları beklenmez; ancak kadınlardan beklenir. Cinsiyetle ilgili sistemi meşrulaştırma ve tecavüz mitlerini kabul yönündeki bu inanç, adaletsizlik ve mağduriyete ilişkin ahlaki öfkenin azalmasıyla ilişkilidir ve bu durum tecavüz için toplumsal cinsiyet eşitsizliğini pekiştirerek sistemi meşrulaştırıcı bir döngü yaratmaktadır.

Cinsiyet sistemi ve ahlaki öfke ilişsisini inceleyen bir başka çalışmada ise (Quasney, 2011), kadınların ahlaki öfke puanlarının erkeklerinkinden daha yüksek olduğu bulunmuştur. Aynı çalışmada, cinsiyet eşitsizliğine maruz bırakılma koşulunda kadınlarla erkeklerin ahlaki öfke puanları arasındaki farkın daha fazla olduğu da bulunmuştur. Ayrıca, düşmanca cinsiyetçiliğin ve korumacı cinsiyetçiliğin ahlaki öfke üzerinde etkili olmadığı; ancak kadınlara yardım programlarına yönelik desteği ahlaki öfkenin pozitif olarak yordadığı; ancak suçluluğun yordamadığı bulunmuştur. Bu sonuçlar, eşitsizlik yönündeki farkındalığın dezavantajlı bir grupta ahlaki öfkeyi artırdığına işaret etmekte ve ahlaki öfkenin olumlu sosyal eylemler üzerindeki pozitif etkisini tekrar ortaya koymaktadır.

Pagano (2007), farklı ahlaki duygularla, farklı olumlu sosyal eylemler arasındaki ilişkileri incelemiştir. Olumlu sosyal eylemler, insani yardım hareketleri (temel desteği sağlamak yönündeki isteklilik), onarıcı eylemler (çalışan yoksul kesimi eşitleme yönündeki isteklilik) ve koruyucu eylemler (sistemi değiştirme yönündeki isteklilik) olmak üzere üç grupta ele alınmıştır. Sonuçlara göre; suçluluk ve ahlaki öfke, insani yardım hareketleri ile onarıcı eylemleri pozitif olarak yordamıştır. Koruyucu eylemler ise empati ve ahlaki öfke tarafından pozitif olarak yordanmıștır. Pagano (2007), çalışmasında son olarak ahlaki duygular ile kişinin psikolojik sağlığı arasındaki ilişkileri incelemiştir. Bu doğrultuda, olumlu sosyal eylemlere yönelik desteği ölçen soruların hem öncesinde hem de sonrasında, durumsal benlik saygısı ve durumsal kaygı olmak üzere iki ölçüm almıştır. Yalnızca olumlu sosyal eylemlere 
yönelik desteğin belirtilmesinden önce suçluluğun düşük benlik saygısını anlamlı bir şekilde yordadığını bulmuştur. Empati ve ahlaki öfke ise ne olumlu sosyal eylemlere yönelik desteğin belirtilmesi öncesinde ne de sonrasında benlik saygısıyla ilişkili bulunmamıştır. Durumsal kaygıyı ise sadece ahlaki öfke, hem olumlu sosyal eylemlere yönelik desteğin belirtilmesi öncesinde, hem de sonrasında, pozitif bir şekilde yordamıştır. Sonuçlar ahlaki öfke açısından değerlendirildiğinde, ahlaki öfkenin hem olumlu sosyal eylemlere yönelik destek açısından hem de psikolojik sağlık açısından önemli bir değişken olduğu görülmektedir.

Lee (2010), ikna sürecinde ahlaki duyguların rolü üzerine odaklanarak, bir sağlık sorununa yönelik ahlaki sorumluluğu yansıtan farklı mesaj çerçevelerinin, sağlıkla ilgili davranışları nasıl etkilediğini araştırmıştır. Araştırmada ahlaki sorumluluğa yönelik yüklemeler 'kişi' ve 'diğeri' olarak değişimlenmiş ve kişinin kendi sorumluluk ihlalini vurgulayan mesajın suçluluk duygusuna, diğerinin sorumluluk ihlalini vurgulayan mesajın ise ahlaki öfkeye neden olacağı varsayılmıştır. Ayrıca kişinin suçluluk duygusunun onarıcı sağlık davranışlarını teşvik edeceği, diğerine yönelik ahlaki öfkenin ise cezalandırıcı davranışları tetikleyeceği varsayılmıştır. Sonuçlar araştırmacının varsayımlarını doğrulamış, ek olarak ahlaki sorumluluğa yönelik mesajın onarıcı eylemlere yönelik destek (örn., "Öldürücü olma potansiyeline sahip üniversite alkol tüketim kültürünü değiştirmenin yollarını bulmalıyız”) üzerindeki etkisine suçluluk duygusunun aracılık ettiği, cezalandırıcı eylemlere yönelik destek (örn., "Alkol firmaları reklamlarında gençleri hedef aldıkları için cezalandırılmalıdır") üzerindeki etkisine ise ahlaki öfkenin aracılık ettiği bulunmuştur.

Yukarıda değinilen araştırmaların da gösterdiği gibi, ahlaki öfke, adaletsizliğin veya ahlaki ihlallerin değerlendirilmesini gerektiren pek çok durumla ilişkilidir ve adaletsiz durumları ortadan kaldırmaya yönelik güçlü bir motivasyonu temsil etmektedir. Bu bulgular ahlaki öfkenin toplumsal adalet ile ilgili çalışmalarda önemli bir değişken olduğunu ortaya koymaktadır. Buna rağmen ülkemizde ahlaki öfke ile ilgili bir çalışmaya rastlanmamıştır. Bu nedenle, bu çalışmada ülkemizde yapılacak çalışmalarda kullanılmak üzere, Ahlaki Öfke Ölçeğinin (Montada ve Schneider, 1989) Türkçeye uyarlaması yapılmıştır.

\section{YÖNTEM}

\section{Katılımcilar}

Araştırmanın örneklemini Ankara'da farklı üniversitelerde okuyan lisans öğrencileri oluşturmaktadır. Çalışmaya toplam 256 kişi katılmıştır ancak çalışmanın örneklemi üniversite lisans öğrencilerinden oluştuğu için lisansüstü öğrencisi olan iki katılımc1 ve uç değerde olan üç katılımcı analiz dışı bırakılmış ve analizler 251 kişi ile yapılmıştır. Son durumda araştırmanın örneklemi 195 kadın (\%77.7), 54 erkek (\%21.5) ve cinsiyet belirtmeyen iki kişiden (\%0.8) oluşmaktadır. Katılımcıların yaş aralığ1 17 ve 27 arasında değişmekte olup yaş ortalaması 19.94'tür (SS = 1.67).

\section{Veri Toplama Araçları}

Ahlaki Öfke Ölçĕği (Ä̈̈̈): Montada ve Schneider (1989) tarafından Almanca olarak geliştirilen Ahlaki Öfke Ölçeği, Wakslak, Jost, Tyler ve Chen (2007) tarafından İngilizceye uyarlanmıştır. AÖÖ, adaletsizlik ve eşitsizlik karşısında hissedilen strese işaret eden (örn., İnsanların adaletsizliğe göz yummasının utanç verici olduğunu düşünürüm) on maddeden oluşan, 9'lu likert tipi (1 = Hiç katılmıyorum, 9 = Tamamen katılıyorum) bir ölçektir. Ölçekten alınan puan arttıkça, ahlaki öfke düzeyi artmakta olup ölçeğin son dört maddesi ters kodlanmaktadır. Montada ve Schneider (1989) tarafından yapılan özgün çalışmanın Cronbach alfa değerine ulaşılamamıştır, ancak Wakslak ve arkadaşları (2007) tarafından yapılan çalışmada ölçeğin Cronbach alfa değeri .90'dır.

Ahlaki Öfke Ölçeğinin Türkçeye Çevrilmesi: Öncelikle ölçeğin İngilizce formu araştırmacı tarafından Türkçeye çevrilmiştir. Sonrasında Türkçe ve İngilizce maddeler alanda uzman üç akademisyene gönderilerek maddeleri dilbilgisi ve anlam açısından incelemeleri istenmiştir. Uzmanların geribildirimleri doğrultusunda maddeler tekrar düzenlenerek Ahlaki Öfke Ölçeği uygulamaya hazır hale getirilmiştir.

Sosyal Baskınlık Yönelimi Ölçeği (SBYÖ): SBYÖ, AÖÖ'nün ölçüt geçerliliğini belirlemek amacıyla kullanılmıştır. Sosyal baskınlık yönelimi, bireylerin kendi gruplarının diğer gruplardan üstün olması, daha iyi bir konumda bulunması ve onlar üzerinde baskınlık kurma yönelimini ifade etmektedir (Pratto ve ark., 1994; Sidanius ve Pratto, 1999). Alanyazında sosyal baskınlık yönelimi ile ahlaki öfke arasında negatif bir korelasyonun olduğuna işaret eden bulgular bulunmaktadır (Tan, Liu, Huang, Zhao ve Zheng, 2016; Tan, Liu, Zheng ve Huang, 2016; Wakslak, Jost, Tyler ve Chen, 2007). 
Sidanius, Pratto ve Bobo (1994) tarafindan geliştirilmiş olan SBYÖ, 16 maddeden oluşmakta ve "kesinlikle katılmıyorum" (1) ile "kesinlikle katılıyorum" (7) arasında değişen 7 dereceli Likert tipi maddelerden oluşmaktadır. Ölçeğin $2,4,7,9,10,12,14$ ve 15 . maddeleri ters kodlanmakta ve ölçekten alınan puan arttıkça sosyal baskınlık yönelimi düzeyi artmaktadır. Ölçeğin özgün çalışmasından elde edilen Cronbach Alfa iç tutarlık katsayısı .89'dur. Ölçeğin Türkçeye uyarlama çalışması Karaçanta (2001) tarafından gerçekleştirilmiştir. Karaçanta'nın (2001) çalışmasında ölçeğin Cronbach Alfa iç tutarlık katsayısı .85 olarak bulunmuştur. Daha yeni bir çalışmada ise ölçeğin faktör yapısı gözden geçirilmiș ve Jost ve Thompson'ın (2000) bulgularıla tutarlı olarak "grup temelli baskınlık” (örn., "Bazen diğer gruplar oldukları yerde tutulmalıdırlar") ile "eşitliğe karşı olma" (örn., "Grupların eşitliği idealimiz olmalıdır") olarak adlandırılan iki faktörlü bir yapıya sahip olduğu anlaşılmıştır (Hasta ve Karaçanta, 2017). Ölçeğin Cronbach Alfa iç tutarlık katsayıları bu faktörler için sırasıyla .70 ve .84 olarak bulunmuştur. Bu çalışmada ise Cronbach Alfa iç tutarlık katsayıları grup temelli baskınlık bileşeni için .76, eşitliğe karş1 olma bileşeni için .86, ölçeğin tümü için .88 olarak bulunmuştur.

Să̆ Kanat Yetkeciliği Ölçeği (SKYÖ): SKYÖ, AÖÖ’nün ölçüt geçerliliğini belirlemek amaciyla kullanılmıştır. Yetkeci kişilerin kendilerinden farklı gördükleri kişilere yönelik saldırganca tutumlar sergiledikleri (Altemeyer, 1996) bilgisinden hareketle, AÖÖ ile arasında negatif bir ilişkinin bulunması beklenmektedir. Adorno ve arkadaşları (1950) tarafından ortaya atılan Yetkeci Kişilik Kuramının psikanalitik bakış açısını eleştiren Altemeyer (1996), yetkeci kişiliğin yetkeci saldırganlık, yetkeci boyun eğme ve geleneksellik olmak üzere üç bileşeninin olduğunu savunmuş ve Sağ Kanat Yetkeciliği adı verdiği kişilik özelliğini ölçmek amacıyla SKYÖ’yü geliştirmiştir. Ölçek "kesinlikle katılmıyorum" (-4) ile "kesinlikle katılıyorum" (+4) arasında değişen, 9 dereceli Likert tipi bir ölçek olup, 22 maddeden oluşmaktadır. İlk iki madde katılımcıyı Likert tipi puanlama sistemine hazırlamak için eklenmiştir. Bu nedenle puanlamaya dâhil edilmemektedir. Ölçeğin 4, 6, 8, 9, 11, 13, 15, 18 ve 21. maddeleri ters kodlanmakta olup, ölçekten alınan puanlar arttıkça yetkecilik düzeyi de artmaktadır (örn., "İnançlarımızı ve ahlaki yapımızı yiyip bitiren geleneksel olmayan değerleri zamanında yok etmezsek, günün birinde ülkemiz yıkılacak").

Ölçeğin Türkçeye uyarlanma çalışması Güldü (2010) tarafından yapılmıştır. Uyarlama çalışması sonucunda iki madde, madde-test korelasyonları .20'nin altında kaldığı için ölçekten çıkarılmıştır. Ayrıca özgün ölçekten farklı olarak, ölçeğin iki faktörlü bir yapısının olduğu sonucuna varılmıştır. 3, 5, 7, 10, 12, 16,17, 19 ve 22. maddelerin toplandığ faktöre Yüksek Sağ Kanat Yetkecilik Boyutu; 4, 6, 8, 9, 11, 13, 15, 18 ve 21. Maddelerin toplandığ faktöre ise Düşük Sağ Kanat Yetkecilik Boyutu adı verilmiştir. Cronbach Alfa iç tutarlık katsayısı Yüksek Sağ Kanat Yetkecilik Boyutu için .82, Düşük Sağ Kanat Yetkecilik Boyutu için .77, tüm ölçek için ise .85 olarak hesaplanmıştır. Bu çalışmada bu değerler sırasıyla $.91, .85$ ve .85 olarak hesaplanmıştır ancak ölçüt geçerliliğini belirlemek amacıyla SKYÖ’nün yalnızca toplam puanı kullanılmıştır.

Demografik Bilgi Formu: Formda katılımcılara yaş, cinsiyet, eğitim, sosyo-ekonomik düzey, anne eğitim durumu gibi demografik bilgiler sorulmuştur.

\section{İșlem}

Ankara Üniversitesi Etik Kurulu'nun onayı alındıktan sonra veri toplama aşamasına geçilmiştir. Uygulamalar sınıf ortamında, ders öncesi veya sonrasında gerçekleştirilmiştir. Katılımcılar, araştırmaya katılıp katılmama konusunda özgür oldukları, rahatsızlık hissettikleri veya devam etmek istemedikleri durumlarda yarıda bırakabilecekleri ve yanıtların bireysel değil toplu olarak değerlendirileceği konusunda bilgilendirilmişlerdir. Ayrıca katılımcılardan bilgilendirilmiş onam formunu okuyup imzalamaları istenmiş, katılımcıların imzalı onayları alındıktan sonra gizliliğin korunması amacıyla ölçek formları ve onam formları birbirinden ayrılmış ve farklı yerlerde toplanmıştır. Ölçekler toplandıktan sonra katılımcıların araştırma ile ilgili soruları yanıtlanmış ve araştırma ile ilgili bilgi verilmiştir.

\section{BULGULAR}

İlk olarak AÖÖ’nün ayırt ediciliği ve homojenliği ile ilgili bilgi edinmek için madde-test korelasyonu analizi yapılmıştır. Analiz sonucunda ölçeğin tüm maddelerinin korelasyon katsayılarının .51 ve .65 arasında değiştiği bulunmuştur (bkz. Çizelge 1). Ölçeğin yapı geçerliğini belirlemek amaciyla temel bileşenler yöntemi kullanılarak açımlayıcı faktör analizi yapılmıştır. Ancak öncelikle kullanılan verilerin faktör analizine uygun olup olmadığı test edilmiştir. Bu amaçla hesaplanan Kaiser-MeyerOlkin (KMO) değerinin .60'ın üzerinde olması (.81) ve Bartlett Sphericity Testinin anlamlı olması $(\chi 2(45)=666.75, p<.001)$, verilerin faktör 
*Ters kodlanan maddeler

$* * \mathrm{p}<.01$

Çizelge 1. Ahlaki Öfke Ölçeğinin Ortalamaları, Standart Sapmaları, Madde-Test Korelasyonları, Faktör Yükleri, Açıklanan Varyans Yüzdeleri ve İç Tutarlılık Katsayıları

\begin{tabular}{|c|c|c|c|c|c|}
\hline $\begin{array}{l}\text { Ahlaki Öfke Ölçeği Maddeleri } \\
\text { (9 madde; Cronbach Alpha=.76) }\end{array}$ & Ort. & $\mathrm{S}$ & Madde-test & 1. & 2. \\
\hline $\begin{array}{l}\text { 1. İnsanların adaletsizlik nedeniyle } \\
\text { mağdur olduğunu öğrendiğim zaman } \\
\text { gerçekten çok öfkelenirim. }\end{array}$ & 8.27 & 1.10 & $.61 * *$ & .72 & \\
\hline $\begin{array}{l}\text { 3. Sosyal adaletsizlik karşısında } \\
\text { ahlaki olarak öfkeli hissederim. } \\
\text { 4. İnsanların işsizlik sonucu haksız }\end{array}$ & 7.67 & 1.71 & $.65 * *$ & .80 & \\
\hline $\begin{array}{l}\text { yere acı çekmesine içten içe } \\
\text { öfkelenirim. }\end{array}$ & 7.63 & 1.58 & $.56 * *$ & .71 & \\
\hline $\begin{array}{l}\text { 5. İnsanların adaletsizliğe göz } \\
\text { yummasının utanç verici olduğunu } \\
\text { düșünürüm. }\end{array}$ & 8.18 & 1.27 & $.51 * *$ & .67 & \\
\hline $\begin{array}{l}\text { 6. Bazı insanların fakir oldukları için } \\
\text { pislik içinde yaşamak zorunda } \\
\text { kaldıklarını öğrendiğimde dehşete } \\
\text { düşerim. }\end{array}$ & 7.55 & 1.72 & $.62 * *$ & .72 & \\
\hline $\begin{array}{l}\text { *7. Bu dünyanın sorunlarını çok } \\
\text { fazla kafama takmam. }\end{array}$ & 6.67 & 2.25 & $.60 * *$ & & .73 \\
\hline $\begin{array}{l}\text { *8. } \mathrm{Bu} \text { dünyadaki haksızlıkları } \\
\text { nadiren kendime yük edinirim. }\end{array}$ & 6.45 & 2.07 & $.57 * *$ & & .80 \\
\hline $\begin{array}{l}\text { *9. Sosyal adalet ile ilgili sorunlar } \\
\text { nadiren aklıma gelir. }\end{array}$ & 7.22 & 1.84 & $.65 * *$ & & .76 \\
\hline $\begin{array}{l}\text { *10. İnsanlar toplumumuzdaki } \\
\text { sorunlardan bahsettiği zaman } \\
\text { duymazliktan gelirim. }\end{array}$ & 8.14 & 1.28 & $.53 * *$ & & .56 \\
\hline Özdeğer & & & & 3.31 & 1.58 \\
\hline Açıklanan varyans (\%) & & & & 30.51 & 23.87 \\
\hline İç tutarlılık katsayısı & & & & .78 & .70 \\
\hline
\end{tabular}

analizine uygunluğunu göstermektedir (Pullant, 2001). Faktör sayısı kısıtlanmadan ve herhangi bir döndürme yöntemi kullanılmadan yapılan temel bileşenler analizi sonucunda özdeğeri 1'in üzerinde olan iki faktör ortaya çıkmış ve bu faktörlerin açıkladıkları toplam varyansın $\% 51.74$ olduğu görülmüştür.

Eğim grafiğinin (scree plot) de iki faktörlü bir yapıya işaret etmesi nedeniyle, analiz iki faktöre zorlanarak ve varimaks rotasyonu kullanılarak tekrar edilmiştir. Ortaya çıkan faktörler, madde içerikleri göz önünde bulundurularak, "duygusal boyut" ve "bilişsel boyut" olarak adlandırılmıştır. Duygusal boyut (DB) altında 1., 3., 4., 5. ve 6. maddelerin, bilişsel boyut (BB) altında ise son 2., 7., 8., 9. ve 10. maddelerin toplandığ1 ve analiz sonucunda, ikinci madde hariç, maddelerin faktör yüklerinin .55 ile .81 arasında değiştiği bulunmuştur. İkinci maddenin (Dezavantajlı kişilere yardım etmek için hep beraber çalışmamız gerektiğine inanırım) faktör yükü ise .31'dir. Bu değer oldukça düşük olduğundan maddenin ölçekten çıkarılmasına karar verilerek varimaks rotasyonu kullanılarak iki faktörlü yapının uygunluğu tekrar sınanmıştır. Analiz sonucunda, maddelerin faktör yüklerinin .56 ile .80 arasında değiştiği görülmüştür. Son durumda, DB varyansın \%30.51'ini, BB ise varyansın $\% 23.87$ 'sini açıklamaktadır. Açıklanan toplam varyans ise $\% 54.38$ 'dir. Ölçeğin Cronbach Alfa iç tutarlık katsayısına bakıldığında ise, bu değerin DB için .78, BB için .70, ölçeğin tamamı için ise .76 
olduğu bulunmuştur. Yapılan faktör analizi sonucunda elde edilen iki boyut arasındaki korelasyon ise .32 'dir $(\mathrm{p}<.001)$. Ölçek maddelerinin ortalama, standart sapma, madde-test korelasyon değerleri, faktör yükleri ve açıklanan varyans yüzdeleri ile iç tutarlılık katsayıları Çizelge 1'de yer almaktadır.

Açımlayıcı faktör analizi ile elde edilen iki faktörlü yapının uygunluğu doğrulayıcı faktör analizi ile de sınanmıştır. Analiz sonucunda elde edilen uyum indeksleri Çizelge 2'de sunulmuştur. Modifikasyon indeksi önerileri doğrultusunda, aynı faktör altındaki 8. ve 9. maddelerin hataları ilişkilendirilmiştir. İki model ki-kare fark testi ile karşılaştırılmış ve ilişkilendirme sonucunda modelin daha uyumlu hale geldiği görülmüştür [ $\chi 2$ fark $(1, N=251)=54.16, p<.001]$. Bu ilişkilendirme sonrasında modifikasyon indeksi önerileri doğrultusunda 4. ve 6. maddelerin hataları ilişkilendirilmiş ki-kare fark testi yeni modelin önceki modelden daha uyumlu olduğunu göstermiştir [ $\chi 2$ fark $(1, \mathrm{~N}=251)=24.84, \mathrm{p}<.001]$. $\mathrm{Bu} \mathrm{kez,} \mathrm{modifikasyon} \mathrm{indeksi} \mathrm{önerileri} \mathrm{doğrultusunda} \mathrm{7.} \mathrm{ve} \mathrm{8.} \mathrm{maddelerin} \mathrm{hataları} \mathrm{ilişkilendirilmiş} \mathrm{ve}$ ki-kare fark testi ilişkilendirme sonucunda modelin daha uyumlu hale geldiğini göstermiştir [ $\chi 2$ fark (1, $\mathrm{N}=251)=19.41, \mathrm{p}<.001]$. Son olarak, 7. ve 9. maddelerin hataları ilişkilendirilerek model daha uyumlu hale getirilmiş $[\chi 2$ fark $(1, \mathrm{~N}=251)=28,70, \mathrm{p}<.001$ ] ve dört hata ilişkilendirmesi sonucunda elde edilen uyum indeksleri, $\chi 2(23, \mathrm{~N}=251)=63.10, \mathrm{p}<.001, \chi 2 / \mathrm{df}=2.74$, GFI $=.95$, AGFI $=.90$, CFI $=.95$ ve RMSEA $=.08$ olarak bulunmuştur (bkz., Çizelge 2 ). $\chi 2 /$ df oranının 3 'ün altında olması ve GFI, AGFI ve CFI uyum indeksi değerlerinin .90'ın üzerinde olması iyi uyumu göstermektedir. RMSEA değerinin de .08 ve altında olması kabul edilebilir uyum olarak kabul edilmektedir.

Çizelge 2. Ki Kare Testi ve Uyum İndeksleri

\begin{tabular}{|c|c|c|}
\hline$\underline{\chi^{2}}$ & \multicolumn{2}{|c|}{ Df $\chi 2 /$ dfRMSEAGFICFIAGFI } \\
\hline $\begin{array}{l}\text { İki faktörlü model } \\
\text { (4 hata ilişkilendirmesi) }\end{array} 63.10$ & 232.74 .08 & $\begin{array}{lll}.95 & .93 & .90\end{array}$ \\
\hline $\begin{array}{l}\text { İki faktörlü model } \\
\text { (3 hata ilişkilendirmesi) }\end{array} 91.80$ & 243.82 .11 & $.92 \quad .88 \quad .85$ \\
\hline $\begin{array}{l}\text { İki faktörlü model } \\
(2 \text { hata ilişkilendirmesi) }\end{array}$ & 254.45 .12 & $\begin{array}{lll}.91 & .85 & .83\end{array}$ \\
\hline $\begin{array}{l}\text { İki faktörlü model } \\
\text { (1 hata ilişkilendirmesi) }\end{array}$ & 5265.23 .13 & $\begin{array}{lll}.89 & .81 \quad .81\end{array}$ \\
\hline İki faktörlü ilk model 190.21 & 277.04 .16 & $.84 .72 \quad .73$ \\
\hline Tek faktörlü model 190.21 & 277.04 .16 & $.84 \quad .72 \quad .73$ \\
\hline
\end{tabular}

Doğrulayıcı faktör analizinin sonuçları, her bir maddenin aldığı yükler ve t değerleri ise Çizelge 3'te verilmiştir. Modeldeki tüm standartlaştırılmış faktör yükleri istatistiksel olarak anlamlıdır. Sonuç olarak AÖÖ’nün iki faktörlü yapısının uygun olduğu görülmektedir.

Çizelge 3. Doğrulayıcı Faktör Analizi Sonuçları

\begin{tabular}{lllll}
\hline \hline & & $\boldsymbol{\beta}$ & $\boldsymbol{t}$ & SH \\
\hline \multirow{3}{*}{ Duygusal Boyut } & M1 & .74 & $10.69^{*}$ & .08 \\
& M3 & .82 & $10.68^{*}$ & .12 \\
& M4 & .53 & $7.51^{*}$ & .14 \\
& M5 & .55 & $7.87^{*}$ & .11 \\
& M6 & .54 & $7.72^{*}$ & .15 \\
\hline \hline \multirow{3}{*}{ Bilişsel Boyut } & M7 & .25 & $2.95^{*}$ & .44 \\
& M8 & .21 & $2.95^{*}$ & .26 \\
& M9 & .37 & $3.70^{*}$ & .33 \\
$* \mathrm{p}<.01$ & M10 & .35 & $3.03^{*}$ & .26 \\
\hline
\end{tabular}


Son olarak AÖÖ’nün ve iki alt faktörünün ölçüt geçerliğini belirlemek amacıyla, AÖÖ ve alt faktörleri ile SBYÖ toplam puanı ve SKYÖ toplam puanı arasındaki korelasyonlara bakılmıştır. Analiz sonucunda bütün korelasyonların anlamlı olduğu ve korelasyon katsayılarının .15 ile .92 arasında değiştiği bulunmuştur. Çizelge 4'te hesaplanan korelasyon katsayıları yer almaktadır.

Çizelge 4. Değișkenler arası korelasyonlar

\begin{tabular}{llllll}
\hline \hline & 1 & 2 & 3 & 4 & 5 \\
\hline 1. AÖÖ & 1 & & & & \\
$2 . \mathrm{DB}$ & $.80^{* *}$ & 1 & & & \\
3. BB & $.83^{* *}$ & $.32^{* *}$ & 1 & 1 & 1 \\
4. SBYÖ & $-.46^{* *}$ & $-.35^{* *}$ & $-.40^{* *}$ & $.35^{* *}$ & 1 \\
$5 . \mathrm{SKYÖ}$ & $-.22^{* *}$ & $-.15^{*}$ & $-.21^{* *}$ & & \\
\hline \hline
\end{tabular}

${ }^{* * *} \mathrm{p}<.01 ;{ }^{*} \mathrm{p}<.05$

AÖÖ = Ahlaki Öfke Ölçeği, DB = Duygusal Boyut, BB = Bilişsel Boyut,

SBYÖ = Sosyal Baskınlık Yönelimi Ölçeği, SKYÖ = Sağ Kanat Yetkeciliği

\section{TARTIŞMA}

Bu çalışmada, Montada ve Schneider'in (1989) Almanca olarak geliştirdiği Ahlaki Öfke Ölçeğinin, Wakslak, Jost, Tyler ve Chen (2007) tarafindan İngilizceye uyarlanan versiyonunun Türkçeye uyarlaması yapılmıştır. Yapılan analizler sonucunda, orijinalinden farklı olarak, ölçeğin iki faktörlü bir yap1 gösterdiği görülmüştür. Madde içerikleri göz önünde bulundurularak bu faktörler "duygusal boyut" (DB) ve "bilişsel boyut" (BB) olarak adlandırılmıştır.

DB'de bulunan maddelerin, dezavantajlı kişilerin yaşadıkları karşısında verilen duygusal tepkileri ifade ettiği (örn., "İnsanların adaletsizlik nedeniyle mağdur olduğunu öğrendiğim zaman gerçekten çok öfkelenirim.”); BB'deki maddelerin ise bilişsel tepkileri ifade ettiği (örn., "Bu dünyanın sorunlarını çok fazla kafama takmam.”) görülmektedir. İlgili alanyazın incelendiğinde, duyguların ve bilişlerin çoğunlukla etkileşim içinde bulundukları ve tamamen bağımsız yapılar olmadıkları görülmektedir (Robinson, Watkins ve Harmon-Jones, Storback ve Clore, 2007). Bu durum ahlaki öfke açısından değerlendirildiğinde, kişinin dünyadaki adaletsiz durumlarla ilgili bilişlerinin ve duygularının tutarlı olması beklenmektedir. Yani adaletsizlikle ilgili bilişsel tepkileri yüksek kişilerin duygusal tepkileri de yüksek olmalıdır. Nitekim, DB ve BB arasındaki korelasyon (.32) bu beklentiye uygundur. Maddelerin faktör yüklerinin oldukça yüksek olması ve doğrulayıcı faktör analizi sonuçlarının iyi ve kabul edilebilir uyuma işaret etmesi de ölçeğin Türkiye örnekleminde iki faktörlü olarak işlediğini ortaya koymaktadir.

Güvenirlik analizleri ölçeğin iç tutarlılık katsayısının .76 olduğunu göstermiştir. Bu değer Wakslak, Jost, Tyler ve Chen (2007) tarafindan elde edilen değerden (.90) düşük olsa da, kabul edilebilir bir değerdir (Field, 2017). Ölçeğin alt boyutları için elde edilen iç tutarlılık katsayıları da (DB için .78; DD için .70) kabul edilebilir sınırlardadır (Field, 2017).

Ölçeğin ölçüt geçerliğini belirlemek için SBYÖ ve SKYÖ kullanılmıştır. Daha önce de bahsedildiği gibi, alanyazın bulguları ahlaki öfkenin sosyal baskınlık yönelimiyle ilişkili olduğuna işaret etmektedir (örn., Tan, Liu, Zheng ve Huang, 2016). Ek olarak yetkeci kişilerin kendilerinden farklı gördükleri kişilere yönelik saldırganca tutumlar sergiledikleri bilinmektedir (Altemeyer, 1996). Sosyal baskınlık yöneliminin iç grup yanlılığı ile ilgili bir yönelim olduğu ve toplumdaki avantajlı grupların, avantajlı durumlarını korumaya ve haklı çıkarmaya yönelik bir işlevinin olduğu bilinmektedir (Pratto, Sidanius, Stallworth ve Malle, 1994; Sidanius ve Pratto, 1999). Sağ kanat yetkeciliği ise bireyin kendinden daha üstün gördüğü kişileri otorite kabul etmesi ve onlara boyun eğmesidir ve "yetkeci saldırganlık" olarak adlandırılan bir tutum öğesini içerir (Altemeyer, 1996; Güldü, 2010, 2011). Buna göre yetkeci kişiler, kendilerinden farklı gördükleri kişiler veya gruplara yönelik saldırgan tutumlar sergilerler. Ahlaki öfkenin en genel ifadeyle bir başkasının hakkaniyetsizlik veya adaletsizlik yaşaması nedeniyle 
hissedilen bir duygu olduğu göz önünde bulundurulduğunda, AÖÖ ile hem SBYÖ hem de SKYÖ arasındaki negatif ilişki alanyazınla tutarlıdır.

Sonuç olarak, analiz sonuçları AÖÖ’nün duygusal ve bilişsel boyut olmak üzere iki faktörlü bir yapıya sahip, geçerli ve güvenilir bir ölçüm aracı olduğunu göstermektedir. Araştırmanın kapsamı dâhilinde yalnızca üniversite öğrencilerinden oluşan bir örneklemden veri toplanmış olması ve buna bağlı olarak yaş ortalamasının oldukça düşük olması (19.94), bulguların genellenebilirliği açısından bir sınırlılık yaratmakla birlikte, sonraki araştırmalarda farklı eğitim düzeyleri ve yaş gruplarından bireylerle yapılacak çalışmalar genellenebilirliğe katkı sağlayacaktır.

Ahlaki öfkenin toplumsal adalet ile ilgili bir duygu olması ve adaletsiz bir durumu ortadan kaldırmaya yönelik güçlü bir motivasyonu temsil etmesi (Montada ve Schneider, 1989; Pagano, 2007; Wakslak, Jost, Tyler ve Chen, 2007) toplumsal adalet ile ilgili çalışmalar açısından önemli bir değişken olduğunu göstermektedir. $\mathrm{Bu}$ nedenle Ahlaki Öfke Ölçeğinin, adaletsizlik, eşitsizlik veya ayrımcılık gibi konularla ilgili toplumsal çalışmalara önemli bir katkı sağlayacağı umut edilmektedir.

\section{KAYNAKÇA}

Adorno, T. W., Frenkel-Brunswik, E., Levinson, D. J., Sanford, R. N., Aron. (1950). The authoritarian personality. Harper and Brothers: New York.

Altemeyer, B. (1996). The authoritarian specter. Harvard University Press: London.

Chapleau, K. M. ve Oswald, D. L. (2014). A system justification view of sexual violence: Legitimizing gender inequality and reduced moral outrage are connected to greater rape myth acceptance. Journal of Trauma \& Dissociation, 15(2), 204-218.

Field, A. (2017). Discovering statistics using IBM SPSS Statistics: North American Edition. Sage.

Flanagan, O. (2018). Introduction: The moral psychology of anger. Myisha Cherry \& Owen Flanagan (Ed.), The Moral Psychology of Anger içinde. (s. VIII-XXXI). Rowman \& Littlefield International.

Güldü, Ö. (2010). Üniversite öğrencilerinde siyasal kimlik (Yayımlanmamış Doktora Tezi). Ankara Üniversitesi, Ankara.

Güldü, Ö. (2011). Sağ Kanat Yetkeciliği Ölçeği: Uyarlama çalışması (Right-Wing Authoritarianism Scale: The adaptation study). Ankara Üniversitesi Sosyal Bilimler Dergisi (Ankara University Journal of Social Sciences), 2(2), 27-51.

Hasta, D. ve Karaçanta, H. (2017). Yetkecilik, sosyal baskınlık yönelimi ve siyasal görüş. Türk Psikoloji Yazıları, 20(40), 23-34.

Hoffman, M. L. (2001). Empathy and moral development: Implications for caring and justice. Cambridge University Press.

Jost, J. T. (2011). System justification theory as compliment, complement, and corrective to theories of social identification and social dominance. David Dunning (Ed.). Social Motivation içinde. (s. 223263). Psychology Press Taylor \& Francis Group, New York.

Jost, J. ve Hunyady, O. (2002). The psychology of system justification and the palliative function of ideology. European Review of Social Psychology, 13(1), 111-153.

Jost, J. T. ve Thompson, E. P. (2000). Group-based dominance and opposition to equality as independent predictors of self-esteem, ethnocentrism, and social policy attitudes among African Americans and European Americans. Journal of Experimental Social Psychology, 36(3), 209-232.

Jost, J. T., Wakslak, C. J. ve Tyler, T. R. (2008), System justification theory and the alleviation of emotional distress: Palliative effects of ideology in an arbitrary social hierarchy and in society. Karen A. Hegtvedt ve Jody Clay-Warner (Ed.), Justice (Advances in Group Processes, Volume 25) içinde (s.181-211). Emerald Group Publishing Limited. 
Karaçanta, H. (2001). Üniversite öğrencilerinin sosyal baskınlık yönelimi ve başka bazı değişkenler açısından karşılaştırılması (Yayınlanmamış doktora tezi). Ankara Üniversitesi, Ankara.

Kugler, M. B., Cooper, J. ve Nosek, B. A. (2010). Group-based dominance and opposition to equality correspond to different psychological motives. Social Justice Research, 23(2-3), 117-155.

Lee, S. Y. (2010). Framing moral responsibility: The influence of moral emotions on persuasive health messages (Yayımlanmamış Doktora Tezi). Universıty of Wisconsin-Madison.

Montada, L. (1992). Predicting prosocial commitment in different social contexts. Pearl M. Oliner, Samuel P. Oliner, Lawrence Baron, Lawrence A. Blum, Dennis L. Krebs, M. Zuzanna Smolenska (Ed.). Embracing the Other: Philosophical, Psychological, and Historical Perspectives on Altruism içinde (s. 226-252). NYU Press, New York..

Montada, L. ve Schneider, A. (1989). Justice and emotional reactions to the disadvantaged. Social Justice Research, 3(4), 313-344.

Pagano, S. J. (2007). A model of moral emotional reactions to injustice: Implications for psychological well-being and prosocial action (Yayımlanmamış Doktora Tezi). University of California, Los Angeles.

Pratto, F., Sidanius, J., Stallworth, L. M. ve Malle, B. F. (1994). Social dominance orientation: A personality variable predicting social and political attitudes. Journal of Personality and Social Psychology, 67(4), 741.

Pullant, J. (2001). SPSS survival manual: A step by step guide to data analysis using SPSS for Windows. Open University Press, Philadelphia, PA.

Quasney, E. (2011). Emotional responses to gender-based inequality: Justifications and consequences (Yayımlanmamış Yüksek Lisans Tezi). Marquette University.

Robinson, M. D., Watkins, E. R., ve Harmon-Jones, E. (Ed.). (2013). Handbook of cognition and emotion. Guilford Press.

Rozin, P., Lowery, L., Imada, S. ve Haidt, J. (1999). The CAD triad hypothesis: a mapping between three moral emotions (contempt, anger, disgust) and three moral codes (community, autonomy, divinity). Journal of Personality and Social Psychology, 76(4), 574.

Sidanius, J. ve Pratto, F. (1999). Social dominance: An 1ntergroup theory of social hierarchy and oppression. Cambridge University Press, New York.

Storbeck, J., ve Clore, G. L. (2007). On the interdependence of cognition and emotion. Cognition and Emotion, 21(6), 1212-1237.

Tan, X., Liu, L., Huang, Z., Zhao, X. ve Zheng, W. (2016). The dampening effect of social dominance orientation on awareness of corruption: Moral outrage as a mediator. Social Indicators Research, 125(1), 89-102.

Tan, X., Liu, L., Zheng, W. ve Huang, Z. (2016). Effects of social dominance orientation and right-wing authoritarianism on corrupt intention: The role of moral outrage. International Journal of Psychology, 51(3), 213-219.

Wakslak, C. J., Jost, J. T., Tyler, T. R. ve Chen, E. S. (2007). Moral outrage mediates the dampening effect of system justification on support for redistributive social policies. Psychological Science, 18(3), 267-274. 